\title{
The effect of interscapular brown adipose tissue removal on body-weight and cold response in the mouse
}

\author{
BY E. CONNOLLY*, R. D. MORRISEY† AND J. A. CARNIE* \\ Departments of ${ }^{*}$ Biochemistry and $\dagger$ Ophthalmic Optics, University of Manchester \\ Institute of Science and Technology, Manchester M60 IQD
}

(Received 12 October 1981- Accepted 22 January 1982)

1. The removal of the interscapular brown adipose tissue (IBAT) led to an increase in body-weight of normal, lean mice as compared to anaesthetized controls.

2. No significant difference in food consumption could be detected between the two groups of mice over the period of the experiment.

3. Fat extraction of the whole carcasses with chloroform: methanol showed a statistically significant increase in fat content in the animals without IBAT.

4. There was no apparent failure in the operated animals to sustain core temperature when exposed to a cold stress situation ( $4^{\circ}$ for $24 \mathrm{~h}$ ).

5. There was no difference in the wet weight, protein content or cytochrome oxidase content of the dorso-cervical brown adipose tissue (DCBAT) between operated and control mice. This is indicative of a lack of proliferation of other brown adipose tissue sites in the operated mice in response to the removal of the IBAT.

6. It is suggested that brown adipose tissue is implicated in dietary thermogenesis in the mouse.

In recent studies the involvement of brown adipose tissue (BAT) in the regulation of body-weight (Rothwell \& Stock, 1979) and core temperature (Foster \& Frydman, 1978) in rats has been well documented. It has been shown that adaptation of rats to a cold environment $\left(4^{\circ}\right)$ leads to an increased capacity for non-shivering thermogenesis (NST) (Foster \& Frydman, 1978). Furthermore, when rats are given a varied and palatable diet, (a 'cafeteria' diet) this also leads to an increased thermogenic capability called dietary induced thermogenesis (DIT) (Rothwell \& Stock, 1979).

In both cold adapted and cafeteria fed rats the increased thermogenic function correlates with an increased interscapular brown adipose tissue (IBAT) weight, protein content, cytochrome oxidase content and mitochondrial guanosine diphosphate (GDP) binding, the last being a direct measurement of the tissue's capacity for uncoupled, heat-producing respiration (Desautels et al. 1978; Ricquier et al. 1979; Brooks et al. 1980).

The phenomena of cold adaptation and 'cafeteria' feeding however lead to chronic changes in BAT and thermogenesis. The mechanism of the acute phase of NST in response to a sharp drop in ambient temperature is still unclear. It does seem that GDP binding to BAT mitochondria in mice increases markedly within the first hour of cold exposure and this is interpreted as an unmasking of the GDP binding sites, i.e. an increased rate of heat production (Himms-Hagen \& Desautels, 1978). However, the relative importance of other tissues in the acute phase of NST has still to be fully investigated.

In view of the work of Himms-Hagen \& Desautels (1978) and Trayhurn \& James (1978), it is perhaps important to look at the effects of IBAT removal in normal mice, since the mouse without IBAT bears a specific resemblance to the obese mouse in that $25-30 \%$ of the capacity for NST is missing. This study attempts to discover whether the removal of IBAT in normal mice causes changes in body-weight control, and response to acute cold stress which may resemble those seen in the obese mouse.

The results demonstrate the involvement of BAT in the regulation of body-weight in mice on a normal stock diet but also suggest that animals without IBAT can respond to acute cold stress in the normal manner. 


\section{Animals and methods}

The animals used in this study were from our stocks of first generation crosses between $\mathrm{C}_{\mathbf{3}} \mathrm{H}$ and Manchester Black mice. Twenty-four male mice were taken at 6-7 weeks of age and divided into two groups, twelve for surgical removal of IBAT (IBATX) and the other twelve for anaesthetized controls. The animals were paired in metal cages containing a layer of sterilized wood shavings and were given free access to food and water. Before having the operations the animals were given several days to acclimatize to the new conditions, that is until their body-weights stabilized. The animal room was maintained at $22^{\circ}$ on a $12 \mathrm{~h}$ light $-12 \mathrm{~h}$ dark cycle, the light coming on at 08.00 hours.

Operations were carried out between 13.00 and 15.00 hours on day 0 of the experiment. IBATX animals were anaesthetized with Saffan (Glaxovet Ltd, Middlesex; $20 \mathrm{mg} / \mathrm{kg}$ body-weight). A small longitudinal incision was made between the shoulder blades and the skin carefully opened out. The Sultzer vein draining the IBAT was located and tied off on the main vessel above the point of branching into the two IBAT lobes. The vein was then cut on the IBAT side of the tie and the two IBAT lobes were quickly and completely removed. The animals were closed and allowed to recover. Control animals were given the same dose of Saffan and were allowed to recover.

Body-weights were taken at 13.00 hours each day to eliminate errors due to the diurnal periodicity in mouse weights. After weighing, the mice were transferred to clean cages with water and fresh, weighed portions of pelleted food (41 B Rat Cube, Pillsbury's, Birmingham). The remaining pellets and the amount of spillage were determined for the previous day's cages and in this way an average food consumption per animal was estimated.

Rectal temperatures were measured using a thin glass probe containing a thermocouple (0.2 mm PTFE NiCr/NiAl, Electroplan, Royston, Herts) which was inserted $15 \mathrm{~mm}$ into the mouse rectum. The thermocouple was connected to an electronic thermometer (Type 1624; Comark Electronics, Littlehampton, Sussex) and it was found that the reading stabilized within $20 \mathrm{~s}$ after probe insertion.

Animals were exposed to cold stress $\left(4^{\circ}\right)$ at 09.00 hours on day 6 of the experiment. Free access to food and water was allowed and the mice were caged in the usual manner. Rectal temperatures were taken just before placing in the cold and at the times indicated in the results. The animals were left in the cold until 09.00 hours next morning when their rectal temperatures were finally taken.

On day 22 the animals were killed with halothane and the dorso-cervical BAT (DCBAT) was quickly dissected out and weighed. The carcasses were also weighed and then placed in a flow-through oven for drying, in preparation for fat extractions.

After weighing, the DCBAT (two lobes from each animal) was homogenized in $1 \mathrm{ml}$ of medium (0.25 M-sucrose, 0.2 mM-EDTA, 1 mM-Hepes, pH 7.2). Samples were taken for protein determination and Lubrol (Sigma London; $3 \mathrm{mg} / \mathrm{mg}$ protein) was added to the remaining homogenate and the mixture was further homogenized for $1 \mathrm{~min}$. The final homogenate was then assayed for cytochrome oxidase activity.

Cytochrome oxidase assay. Cytochrome oxidase was assayed polarographically at $37^{\circ}$ in a Clark oxygen electrode containing an incubation medium of the following composition: 77.5 mm-potassium phosphate buffer, $\mathrm{pH} \mathrm{6.6,0.1} \mathrm{mM-cytochrome} c$ (Type III, horse heart; Sigma, London) and $20 \mathrm{~mm}$-sodium ascorbate. A sample of homogenate (approximately $200 \mu \mathrm{g}$ ) was incubated in a final volume of $3 \mathrm{ml}$. The reaction was started by the addition of ascorbate.

Fat extractions. The dried carcasses were minced with scissors and placed in a soxhlet apparatus. They were each extracted for $9 \mathrm{~h}$ in chloroform-methanol $(2: 1, \mathrm{v} / \mathrm{v})$. The extract was dried to constant weight and the fat content calculated. 


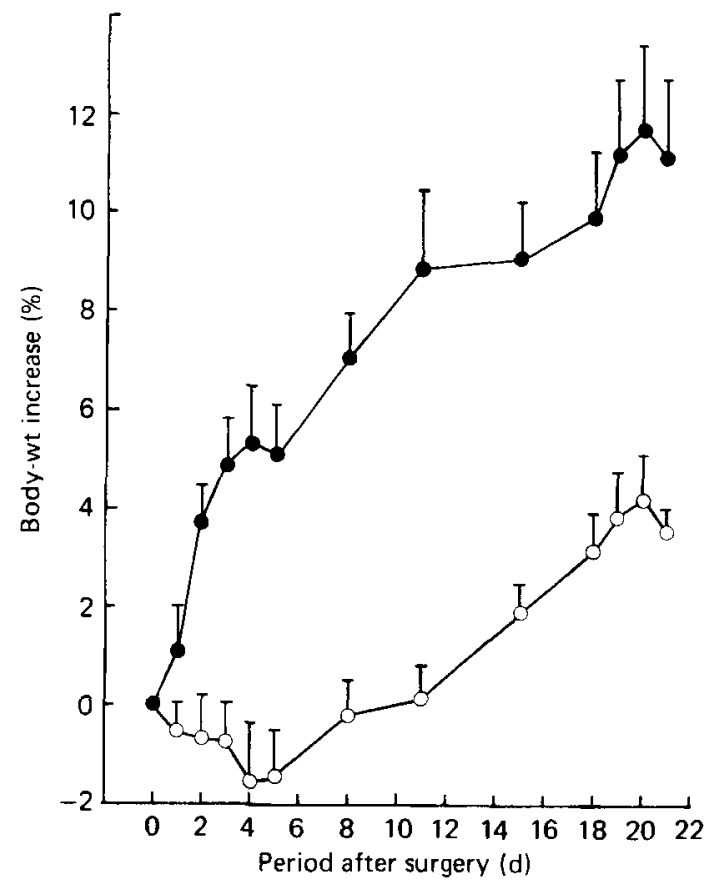

Fig. 1. The effect of interscapular brown adipose tissue removed surgically (IBATX) on body-weight $(\%$ increase) in mice. Day 0 is the day of the surgical operations and the post-operative weight on this day was taken as the zero weight from which the percentage changes were calculated $(O)$, IBATX; (O), anaesthetized controls. Points are mean values with their standard errors represented by vertical bars, for twelve mice/group. On all days except day 1, IBATX weights are significantly different (Student's $t$ test) from controls $(P<0.001)$.

Protein determination. Protein content of the samples was determined by a modified Lowry method (Schacterle \& Pollack, 1973) after precipitation with trichloroacetic acid $(100 \mathrm{~g} / \mathrm{l})$.

\section{RESULTS}

Following the surgical removal of IBAT, body-weight of the mice increased rapidly compared to anaesthetized controls for approximately $12 \mathrm{~d}$ as shown in Fig. 1. The most rapid increase occurred from day 0 to approximately day 5 and during this period the controls lost almost $2 \%$ of their body-weight whilst the IBATX mice gained almost $6 \%$. We have demonstrated in this laboratory that administration of Saffan $(20 \mathrm{mg} / \mathrm{kg}$ body-weight) causes a reduction in mouse body-weight which the animals do not regain for approximately $6 \mathrm{~d}$, although during this period food and water are consumed at normal levels (Connolly, Morrisey and Carnie, unpublished results). This explains why the control mice lose weight initially.

It is therefore evident that IBAT removal led to an increase in body-weight which masks an initial, expected weight loss due to the anaesthetic. The weight difference on day $12(8 \%)$ is maintained between the two groups until the end of the experiment. For this reason the weight gain cannot be due to oedema as this would be a short-term effect. Furthermore, we could find no evidence of oedema around the IBAT region in any of the mice.

When calculated on a body-weight basis, there was no difference in food consumption between the two groups (Table 1). The animals without IBAT, therefore, appear to have an increased efficiency of energy utilization compared to the controls, a higher proportion 
Table 1. Food consumption and body fat content in IBATX and control mice

(Mean values with their standard errors; no. of observations in parentheses)

\begin{tabular}{|c|c|c|c|c|c|c|c|}
\hline \multirow[b]{2}{*}{ Group } & \multicolumn{2}{|c|}{ Daily food intake: } & \multirow{2}{*}{$\begin{array}{c}\text { Final } \\
\text { body-weight } \\
\text { (g) }\end{array}$} & \multirow{2}{*}{$\begin{array}{c}\text { Body fat* } \\
\text { (g) }\end{array}$} & \multirow{2}{*}{$\begin{array}{c}\text { Fat free } \\
\text { mass } \\
\text { (g) }\end{array}$} & \multirow{2}{*}{$\begin{array}{c}\text { Body fat }+ \\
(\%)\end{array}$} & \multirow{2}{*}{$\begin{array}{c}\text { Body } \\
\text { water+ } \\
(\%)\end{array}$} \\
\hline & (g) & $\left(\mathrm{kJ} / \mathrm{W}^{0 \cdot 75}\right)$ & & & & & \\
\hline IBATX & $5 \cdot 20 \pm 0 \cdot 09$ & $1108 \pm 17$ & $\begin{array}{c}25 \cdot 54 \pm 1 \cdot 36 \\
(10)\end{array}$ & $\begin{array}{c}2 \cdot 96 \pm 0 \cdot 20 \\
(10)\end{array}$ & $\begin{array}{c}22 \cdot 58 \pm 1 \cdot 24 \\
(10)\end{array}$ & $\begin{array}{c}11 \cdot 67 \pm 0.54 \\
(10)\end{array}$ & $\begin{array}{c}67 \cdot 51 \\
(12)\end{array}$ \\
\hline Controls & $5 \cdot 12 \pm 0.07$ & $1103 \pm 17$ & $\begin{array}{c}26 \cdot 33 \pm 1 \cdot 32 \\
(10)\end{array}$ & $\begin{array}{c}2 \cdot 50 \pm 0 \cdot 12 \\
(10)\end{array}$ & $\begin{array}{c}23 \cdot 84 \pm 1 \cdot 17 \\
(10)\end{array}$ & $\begin{array}{c}9 \cdot 57 \pm 0.34 \\
(10)\end{array}$ & $\begin{array}{c}67 \cdot 39 \\
(12)\end{array}$ \\
\hline
\end{tabular}

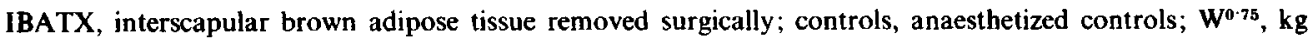
body-weight ${ }^{0-75}$.

* Fat content was estimated by chloroform:methanol extraction.

$\dagger$ Values are statistically significantly different (Student's $t$ test): $P<0.005$.

$\ddagger$ Body water was estimated by oven drying.

of their intake being stored. This idea is further strengthened by the increased fat content of the IBATX animals (Table 1). Percentage body fat in the IBATX mice is increased by $22 \%$ (Table 1) whereas fat free mass and percentage body water are similar, indicating that the rise in body-weight can be confidently ascribed to fat deposition.

It can be seen from Fig. 2 that the response of mice with no IBAT to acute cold stress is normal. Even after $24 \mathrm{~h}$ there was no difference between the two groups indicating a normal response throughout a period where NST should be becoming increasingly important compared to shivering thermogenesis in the maintenance of body temperature. Since the animals were cold exposed on day 6 it is possible that by that time other BAT sites may have compensated for the removed tissue and hence no defect would be observed. The lack of proliferation of other sites is perhaps indicated by the weight gain which is still rapid on day 6. Table 2 shows the results of the dissection of the DCBAT on day 22 . It can be seen that the wet weight of DCBAT/g body-weight on day 0 is identical for IBATX

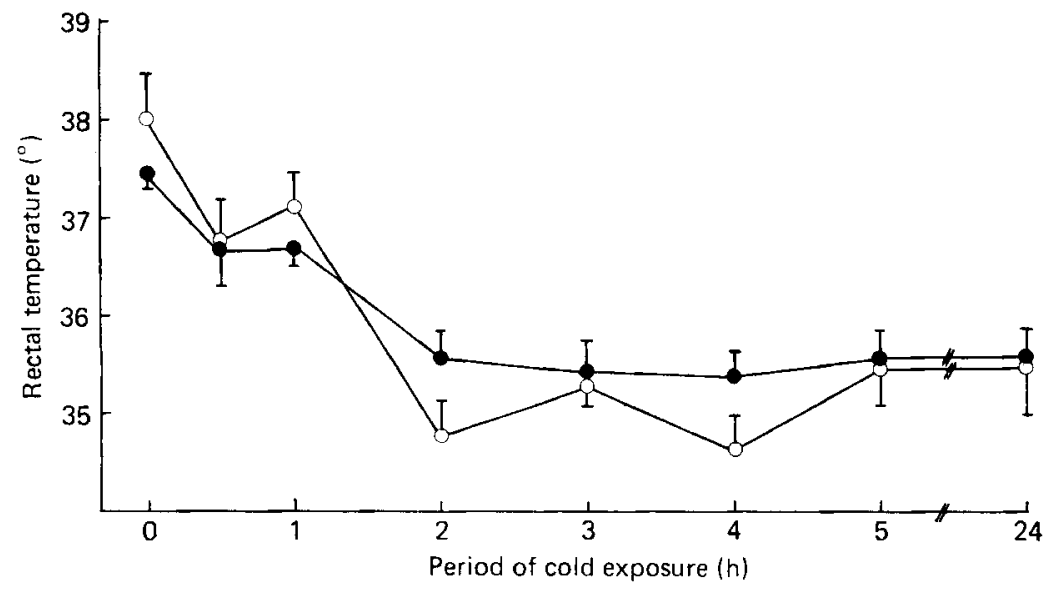

Fig. 2. The effect of interscapular brown adipose tissue removal (IBATX) on the acute cold response of mice exposed to a temperature of $4^{\circ}$. They were given free access to food and water. Rectal temperatures were measured with a thermocouple attached to a Comark electronic thermometer, $(\mathbf{O})$, IBATX; $(\mathrm{O})$, anaesthetized controls. Points are mean values with their standard errors for twelve mice/group. 
Table 2. Properties of dorso-cervical brown adipose tissue dissected from IBATX and normal mice on day 22

(Mean values with their standard errors for twelve mice/group)

\begin{tabular}{|c|c|c|c|c|c|}
\hline \multirow[b]{2}{*}{ Group } & \multirow[b]{2}{*}{$\begin{array}{l}\text { Wet weight } \\
\text { (mg) }\end{array}$} & \multirow[b]{2}{*}{$\begin{array}{l}\text { Relative wt } \\
\text { (mg/g initial } \\
\text { body-wt)* }\end{array}$} & \multirow[b]{2}{*}{$\underset{\text { protein }}{\text { Total }}$} & \multicolumn{2}{|c|}{ Cytochrome oxidase activity } \\
\hline & & & & $\begin{array}{c}\text { Total } \\
(\mu \mathrm{mol} \text { oxygen } / \mathrm{min})\end{array}$ & $\begin{array}{c}\text { Specific } \\
\text { activity } \dagger \\
\text { (umol oxygen/min } \\
\text { per mg protein) }\end{array}$ \\
\hline $\begin{array}{l}\text { IBATX } \\
\text { Controls }\end{array}$ & $\begin{array}{l}15 \cdot 20 \pm 0.70 \\
15 \cdot 33 \pm 1 \cdot 43\end{array}$ & $\begin{array}{l}0.54 \pm 0.04 \\
0.54 \pm 0.03\end{array}$ & $\begin{array}{l}2 \cdot 14 \pm 0 \cdot 17 \\
2 \cdot 47 \pm 0 \cdot 17\end{array}$ & $\begin{array}{l}1 \cdot 48 \pm 0 \cdot 14 \\
1 \cdot 70 \pm 0 \cdot 21\end{array}$ & $\begin{array}{l}0.69 \pm 0.03 \\
0.69 \pm 0.08\end{array}$ \\
\hline
\end{tabular}

IBATX, Interscapular brown adipose tissue removed surgically; controls, anaesthetized controls.

- Initial body-weight on day zero following the operations.

$\dagger$ Cytochrome oxidase activity per mg dorso-cervical brown adipose tissue protein, as measured polarographically.

and controls. If the DCBAT (and other BAT sites) had proliferated then one would expect the IBATX value to be increased above the controls' value. Protein and cytochrome oxidase content were similar also indicating a lack of hypertrophy of other BAT regions. Furthermore, there was no regeneration of BAT in the IBAT site in any of the animals that had undergone surgical removal of the tissue.

\section{DISCUSSION}

BAT has been implicated in two major instances of heat production in the rat. Firstly, cold adapted rats (chronic cold response) have an increased total BAT content (Foster $e t$ al. 1980), and the blood flow to all sites of BAT is increased compared to warm adapted controls (Foster \& Frydman, 1978). Furthermore, the response of the tissue to noradrenaline is elevated compared to warm adapted controls. Infusion of noradrenaline into the plasma leads to an enhanced blood flow to BAT as well as a raised oxygen consumption (Foster \& Frydman, 1978). Secondly, when mild obesity is induced in normal rats by feeding a 'cafeteria' diet, all BAT sites hypertrophy, receive an increased blood flow, and show an increased response to noradrenaline (Rothwell \& Stock, 1981), and these findings indicate a role for BAT in DIT.

In the present work, mice with IBAT removed gained weight rapidly compared to controls, and the increase was attributable to an increase in body fat $(P<0.005$; Table 1$)$. After approximately $12 \mathrm{~d}$ the rate of weight gain of mice without IBAT became synchronous with that of the controls (Fig. 1). Given the very small mass of IBAT the effect its removal has on energy balance is remarkable and indicates a role for BAT in DIT in the mouse. However, no change in the amount or composition of DCBAT occurred after $22 \mathrm{~d}$ (Table 2), and increases in DCBAT reflect changes in total BAT on cold adapted and 'cafeteria-fed' rats. (Foster et al. 1980; Rothwell \& Stock, 1981). Since it appears that removal of IBAT, which accounts for approximately one-third of the total BAT in the mouse (Thurlby \& Trayhurn, 1980), is not compensated for at other BAT sites, the factor involved in the decrease in rate of weight gain at approximately $12 \mathrm{~d}$ after IBAT removal remains unclear.

The involvement of BAT in the acute cold response in the lean mouse has been studied in terms of regional blood flow following noradrenaline infusion (Thurlby \& Trayhurn, 1980) and GDP-binding in BAT mitochondria of cold-exposed mice (Himms-Hagen \& 
Desautels, 1978). We felt it would be beneficial to look at the function of this tissue from another standpoint in which the IBAT is surgically removed and the response to acute cold-stress is monitored.

A further consideration prompted us to look at the effects of IBAT removal in the normal mouse. In the genetically obese mouse the lesion is thought to reside in a failure to respond to short term cold exposure (acute cold response) due to a $20 \%$ reduction in the capacity for NST compared to lean mice at all temperatures below thermoneutrality (Trayhurn \& James, 1978). Since obese mice have the ability to shiver normally (Davis \& Mayer, 1954) it is a direct consequence of the reduced capacity for NST that at $4^{\circ}$ the obese mouse dies after approximately $3 \mathrm{~h}$. The role of BAT in the acute cold response is not well understood but this tissue does show altered properties in the obese mouse. The binding of GDP to BAT mitochondria is reduced compared with lean controls, and exposure to $4^{\circ}$ does not induce the usual increase in binding (Himms-Hagen \& Desautels, 1978). However, the obese mouse does adapt to exposure to cold at $4^{\circ}$ if it is first maintained at an environment of $14^{\circ}$ for 2 weeks. Under these conditions there is no increase in the weight of BAT (in contrast to cold adapted and 'cafeteria-fed' rats, and cold adapted lean mice) but protein content and cytochrome oxidase activity of the tissue doubles, indicating that tissue growth and mitochondrial proliferation occur (Hogan \& Himms-Hagen, 1980).

Removal of IBAT did not prevent mice from maintaining their body temperature when exposed to cold stress at $4^{\circ}$ (Fig. 2). If the lesion in the obese mouse is associated with impaired NST in BAT alone, removal of approximately $30 \%$ of this tissue in normal mice might be expected to show an impairment in the acute cold response similar to that of the obese mouse. Since shivering thermogenesis cannot compensate for an impairment in NST in the obese mouse it is possible that a similar lack of compensation occurs in animals without IBAT.

There are two possible explanations for the unimpaired response to cold in the mice with IBAT removed. Either BAT is not involved in the acute phase of NST, or an increased blood flow to, and an increased $\mathrm{O}_{2}$ uptake by the remaining BAT sites on cold exposure maintain body temperature in mice without IBAT. This latter explanation is the more likely in view of the strong evidence associating NST with BAT.

Considerable work remains to be done on the function of IBAT in NST and DIT in different species. The removal of IBAT, 'cafeteria' feeding and cold exposure represent differing degrees of imposed stress on an animal and there may well be a stress threshold which must be reached before a response in weight and metabolic activity of BAT is observed. Presently we are examining these variables in detail in the mouse.

The authors wish to thank Mr N. Ritchie and Mr S. Butler for their assistance. E.C. acknowledges the receipt of an SERC research studentship.

\section{REFERENCES}

Brooks, S. L., Rothwell, N. J., Stock, M. J., Goodbody, A. E. \& Trayhurn, P. (1980). Nature, Lond. $286,274$.

Davis, T. R. A. \& Mayer, J. (1954). Am. J. Physiol. 177, 222.

Desautels, M., Zaror-Behrens, G. \& Himms-Hagen, J. (1978). Can. J. Biochem. 56, 378.

Foster, D. O., Depocas, F. \& Frydman, M. L. (1980). Can. J. Physiol. Pharmacol. 58, 915.

Foster, D. O. \& Frydman, M. L. (1978). Can. J. Physiol. Pharmacol. 56, 110.

Himms-Hagen, J. \& Desautels, M. (1978). Biochem. Biophys. Res. Comm. 83, 628.

Hogan, S. \& Himms-Hagen, J. (1980). Am. J. Physiol. 239, E301.

Ricquier, D., Mory, G. \& Hemon, P. (1979). Can. J. Biochem. 57, 1262.

Rothwell, N. J. \& Stock, M. J. (1979). Nature, Lond. 281, 31.

Rothwell, N. J. \& Stock, M. J. (1981). Pfiügers Arch. 389, 237.

Schacterle, G. R. \& Pollack, R. L. (1973). Analyt. Biochem. 51, 654.

Thurlby, P. L. \& Trayhurn, P. (1980). Pflügers Arch. 385, 193.

Trayhurn, P. \& James, W. P. T. (1978). Pflügers Arch. 373, 189. 